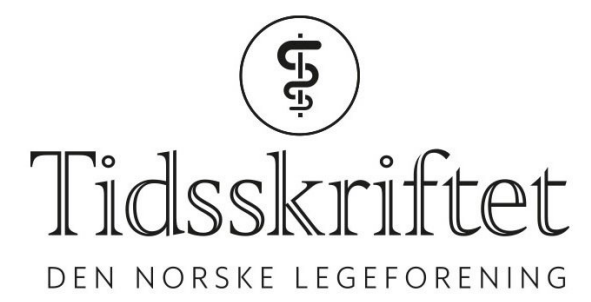

\title{
En blodflekk - til hva og for hvem?
}

KOMMENTAR

\section{GRETE ALHAUG}

E-post: gral@datatilsynet.no

Grete Alhaug er seniorrådgiver i Datatilsynet.

Ingen oppgitte interessekonflikter.

Takk til Are Brean for hans lederartikkel om nyfødtscreening (1). Datatilsynet ønsker å vise hvorfor det er så viktig at de som fatter beslutningene i denne saken innser at behovet for varig lagring ikke er relatert til nyfødtscreeningens arbeid.

Datatilsynet er ikke uenig i at generell medisinsk forskning i likhet med nyfødtscreeningen er et nyttig formål. Vi mener forskning er et annet formål enn det prøvene er samlet inn for og at det er feil å legge til grunn at det samtykkes til forskning i forbindelse med screeningen. Vi mener at Stortinget med dette forslaget er gitt i oppgave å vurdere om det er greit at staten legger til grunn at vi ønsker å bidra til forskning med mindre vi aktivt reserverer oss mot det. Vi mener dette er et stort og viktig spørsmål som ikke er av betydning for nyfødtscreeningens virksomhet og som derfor krever en egen utredning.

Til tross for at varig lagring ikke er nødvendig for å oppnå formålet med nyfødtscreeningen, legger man til grunn at samfunnsnytten vi får gjennom screeningen veier opp for personvernulempene det har for de screenede barna at blodprøvene lagres for evig tid. Denne sammenblandingen av formål gjør det vanskelig å stole på at det er foretatt en reell vurdering av risiko- og personvernkonsekvenser ved varig lagring. At slike vurderinger gjøres på riktig grunnlag er avgjørende for å sikre en veloverveid konklusjon.

Vi mener også at regjeringen har oversett kompleksiteten i det regelverket som i dag ligger til grunn for at vi har stor oppslutning om nyfødtscreening. En rekke unntak og særreguleringer bidrar til at blodprøvene kan samles inn på den måten det gjøres i dag, uten uttrykkelig samtykke fra foreldrene.

Loven sier at forskningsbiobanker skal opprettes med hjemmel i helseforskningsloven (Behandlingsbiobankloven $\S 3$ fjerde ledd). Behandlingsbiobankloven gjelder ikke biobanker som har forskning som formål, og vi mener derfor at det er feil å legge avgjørende vekt på forskningsmiljøenes behov når man skal fastsette lagringstid for blodprøver i en diagnostisk biobank.

Når det gjelder mulige konsekvenser av lovforslaget understreker vi at rettslig regulering ikke er en garanti mot uventede eller utilsiktede personvernkonsekvenser for befolkningen. Risikoen for at genetiske opplysninger benyttes til formål som er uforenelig med befolkningens og samfunnets interesser, er ikke identifisert eller analysert i lovforslaget. At regjeringen allikevel mener forslaget ikke får konsekvenser av betydning for de screenede barnas grunnleggende rettigheter er bekymringsfullt, men kan muligens forklares med at 
lovforslaget ikke skiller mellom formålet med nyfødtscreeningen og andre formål.

LITTERATUR:

1. Brean A. En blodflekk. Tidsskr Nor Legeforen 2018; 138:317.

Publisert: 17. april 2018. Tidsskr Nor Legeforen. DOI: 10.4045/tidsskr.18.0230

(C) Tidsskrift for Den norske legeforening 2020. Lastet ned fra tidsskriftet.no 